\title{
Moving residence in later life: actively shaping place and well-being
}

\author{
By Manik Gopinath ${ }^{1}$, VikKi ENTWISTLE ${ }^{2}$, Timothy B. KeLLY $Y^{3} \mathcal{E}$ \\ BARBARA ILLSLEY
}

\begin{abstract}
Policy discourse favours the idea of "ageing in place" but many older people move home and into different kinds of residential settings. This article extends the understanding of how relocation can promote as well as diminish older people's well-being. Using relational understandings of place and capabilities (people's freedoms and opportunities to be and to do what they value) we explored well-being across the relocation trajectories of 21 people aged 65-91 years living in diverse residential settings in Scotland. We found that a diverse array of capabilities mattered for well-being and that relocation was often motivated by concerns to secure "at-risk" capabilities for valued activities and relationships. Moving residence impacted several other capabilities, in addition to these, both, positively and negatively. We suggest that a capability approach offers a valuable lens for understanding and supporting well-being through
\end{abstract}

${ }^{1}$ Manik Gopinath, School of Health, Wellbeing and Social Care, The Open University, Milton Keynes, UK

${ }^{2}$ Vikki Entwistle, Institute of Applied Health Sciences, School of Divinity, History, Philosophy \& Art History, University of Aberdeen, Aberdeen, UK

${ }^{3}$ Timothy B. Kelly, School of Education and Social Work, University of Dundee, Dundee, UK

${ }^{4}$ Barbara Illsley, School of Social Sciences, University of Dundee, Dundee, UK 
International Journal of Ageing and Later Life

relocation, with potential to overcome some key limitations of dominant behavioural models of late-life relocation.

Keywords: ageing, capability approach, housing, residential relocation, well-being.

\section{Introduction}

In Western contexts, the idea of "ageing in place" - of supporting older people to continue to live in their usual, perhaps long-term homes - has featured prominently in policy discourse. "Ageing in place" emphasises people's positive attachment to their homes and frames late-life residential relocation as undesirable (Andrews et al. 2007). For various reasons some older adults do not - perhaps cannot - remain in their long-term homes and move either to other mainstream housing or to more institutional settings with varying degrees of formal support. (Table 1 summarises the main types of residential settings in the United Kingdom [UK]).

This article aims to extend the understanding of how relocation in later life can promote as well as diminish people's well-being. It reports findings from a study of well-being among older people living in different kinds of accommodation in Dundee, Scotland. Previous research has tended to consider reasons for moving separately from experiences of moving, and sometimes neglects older people's own perspectives on what matters for their well-being. Our findings will illustrate how a more holistic view of the process of moving, and a capabilities approach to analysing well-being, can help avoid the limitations of some previous approaches.

The article begins with an overview of previous research on relocation in later life. We then briefly introduce the conceptual lenses of capabilities and place that guided our investigation, before describing our study context and methods and reporting the key findings related to relocation and well-being.

\section{Previous Literature on Relocation}

Two sizeable bodies of literature offer insights into different aspects of relocation in later life. One focuses on understanding the patterns of 
Table 1. Different types of supported settings in the UK

\begin{tabular}{|c|c|c|c|}
\hline & \multicolumn{2}{|c|}{ Supported housing } & \multirow{2}{*}{$\begin{array}{l}\text { Residential care } \\
\text { homes }\end{array}$} \\
\hline & Sheltered & $\begin{array}{l}\text { Very sheltered/ } \\
\text { extra care }\end{array}$ & \\
\hline Key features & \multicolumn{2}{|c|}{$\begin{array}{l}\text { Purpose built accessible housing } \\
\text { schemes, including various combi- } \\
\text { nations of self-contained bungalows, } \\
\text { apartments and houses, with shared fa- } \\
\text { cilities (e.g. laundry, a common room). } \\
\text { When age segregated, are typically for } \\
\text { over 55- or 60-year olds. }\end{array}$} & $\begin{array}{l}\text { Small or large } \\
\text { scale residential } \\
\text { including nursing } \\
\text { homes that typi- } \\
\text { cally combine en- } \\
\text { suite rooms with } \\
\text { communal facil- } \\
\text { ities (e.g., shared } \\
\text { social spaces, } \\
\text { dining facilities, } \\
\text { gardens) }\end{array}$ \\
\hline $\begin{array}{l}\text { Service and care } \\
\text { provision }\end{array}$ & $\begin{array}{l}\text { Low level service } \\
\text { support, via ei- } \\
\text { ther on or off-site } \\
\text { scheme manager } \\
\text { or warden. Facil- } \\
\text { itated access to } \\
\text { emergency ser- } \\
\text { vices, including } \\
\text { community alarm } \\
\text { services. }\end{array}$ & $\begin{array}{l}\text { High level of care } \\
\text { and support, in- } \\
\text { cluding on-site } \\
\text { availability of } \\
\text { personal care staff. } \\
\text { Services include } \\
\text { housekeeping, } \\
\text { laundry, meals, on- } \\
\text { site warden, emer- } \\
\text { gency community } \\
\text { alarm services. }\end{array}$ & $\begin{array}{l}\text { Highly specialised } \\
\text { levels of personal } \\
\text { care and support } \\
\text { for people with a } \\
\text { range of physical, } \\
\text { cognitive impair- } \\
\text { ments and med- } \\
\text { ical needs. Some } \\
\text { include qualified } \\
\text { nursing care. }\end{array}$ \\
\hline Comparable terms & $\begin{array}{l}\text { 'Congregate se- } \\
\text { nior housing', 'in- } \\
\text { dependent living } \\
\text { facility' (United } \\
\text { States), 'senior } \\
\text { cohousing' (Neth- } \\
\text { erlands, Sweden) } \\
\text { (Choi 2004). }\end{array}$ & $\begin{array}{l}\text { 'Assisted living } \\
\text { facilities' (USA) } \\
\text { (Hillcoat-Nalle- } \\
\text { tamby 2014) }\end{array}$ & $\begin{array}{l}\text { Since April 2002, } \\
\text { in the UK both } \\
\text { residential and } \\
\text { nursing homes } \\
\text { come under } \\
\text { the category of } \\
\text { residential care } \\
\text { homes. In other } \\
\text { Western contexts, } \\
\text { the term 'nursing } \\
\text { home' is com- } \\
\text { monly used }\end{array}$ \\
\hline
\end{tabular}


International Journal of Ageing and Later Life

and reasons for moving from long-term homes and the other focuses on experiences of settling into new places.

\section{Patterns of, and reasons for, relocation}

Studies within this body of literature have informed and mostly been guided by three theoretical models: Litwak and Longino's "typology of relocation" model (1987), Lawton's "ecological model of ageing" (1977) and Wiseman's behavioural model of late-life migration (1980). Litwak and Longino identified three main types of move among American older adults. On their typology, first moves are typically long-distance, and lifestyle related, at retirement. Second and third moves are more typically motivated by increasing healthcare and support needs. They are often short-distance relocations to be closer to adult children or to transition into institutional care.

Bloem et al. (2008) objected that relocation trajectories do not neatly map on to Litwak and Longino's typology. They highlighted severity of health conditions as an additional influence on relocation. Other authors have also noted the influence of cultural preferences and concerns around accessing informal support (Peace et al. 2011), issues of home ownership (McCann et al. 2012) and quality of parent-child relationships (Jennings et al. 2014).

Lawton's ecological model posits that with declining health and age, interactions between people's "personal competences" (typically related to activities of daily living) and home environments influence (usually limit) their behaviour and affective states. For example, difficulty climbing stairs in a building with no lifts will reduce well-being. If environmental barriers cannot be addressed "in situ," people may relocate to settings more suitable to their personal competences. Lawton's model has been critiqued for neglecting considerations such as socio-economic contexts (Renaut et al. 2015), meaningful attachments to places of residence (Cutchin 2001) and the roles of significant others in people's lives (Thomése \& Broese van Groenou 2006). Several authors have also been concerned about the limited attention paid to changes in neighbourhoods (Phillipson 2007) and the implications of neighbourhood deprivation (Smith 2009). The limited conceptions of person-environment in Lawton's model can also lead to neglect of the complexity of interactions between the two, and therefore outcomes are inappropriately seen as more determined than emergent. 
Wiseman's (1980) behavioural decision-making model of migration focuses on the "push and pull factors" underlying relocation. It seeks to explain how older adults weigh up various push and pull factors. Various studies have identified a range of both push factors (including declining health, widowhood, unsuitable housing or neighbourhood environments and difficulty in maintaining housing) and pull factors (including proximity to family and friends, suitable housing, better neighbourhood amenities and attachment to place) (Bekhet et al. 2009; Croucher 2008).

Wiseman's model is criticised for inappropriately assuming that each older adult acts as an independent or autonomous agent in decisions to move. In practice, decisions are often influenced by family members, service providers and various structural factors (Ball et al. 2009; Nygren \& Iwarsson 2009; Portacolone 2013). The model seems to over-individualise the process and understate the complexity of decision-making, especially during stressful life events (Pope \& Kang 2010).

All three models offer some useful insights into the migration patterns of older adults and their reasons for relocation. However, they can tend to focus attention on limited, standard sets of variables, so perhaps foster neglect of people's own experiences of declining well-being and perspectives on what matters about where they live.

\section{Experiences of settling into new settings}

A second body of research focuses on how older people settle in following a move to a new setting. This research has looked primarily at moves into supported, institutional settings, reflecting concerns underpinning the advocacy of "ageing in place" (Luborsky et al. 2011).

Early research focused on documenting the negative impacts (e.g. mortality) of moving into residential care settings (Golant 2003). More recent research employing phenomenological and relational approaches (Cutchin et al. 2003; Jungers 2010) suggests mixed experiences. While some people who move into residential care settings report loss of privacy, loss of independence, fear of death and sadness, others experience a sense of relief, security, and welcome increase in social interaction (Lee et al. 2013). Similarly, some who move into supported housing report grief, anticipatory fear of death, stress or difficulty in communal living, and others describe feeling safe, socially engaged and purposeful (Walker \& McNamara 2013). 
International Journal of Ageing and Later Life

Attempts to explain why some people adjust better than others suggest that good adjustment can be fostered by maintaining control over decision-making and continuity of personal routines and identity (Lee et al. 2013), personalising spaces with material possessions (Leith 2006), developing positive relationships with staff and other residents (Jungers 2010), and pursuing meaningful activities (Petersen \& Minnery 2013).

There is currently, however, limited understanding of whether and to what extent reported experiences with moving are linked to people's reasons for moving or relate to other aspects of their lives. We believe that this gap arises partly because moving out of a current residence and into a new setting have often been studied separately. One under-explored possibility is that people's experiences of settling into a new residence are somehow tied - at least in part - to their motivations for moving and aspects of the moving process. Two studies have looked explicitly at changes in well-being following a move. Finney and Marshall (2018) used data from the English Longitudinal Study of Ageing (ELSA) to examine changes in well-being for community-dwelling older adults. They did not consider the kind of settings or locations that people moved into but identified post-move improvements on hedonic and eudaimonic dimensions of well-being, including among people who moved for non-voluntary reasons such as job relocation or eviction. Ewen and Chahal (2013) used mixed methods to investigate the experiences of 26 American older women who moved into supported housing. They reported improvements in positive affect 3 months after moving, both for women who had and who had not made the decision to move themselves. Both studies confirmed changes in well-being, but it remains unclear whether reported changes are manifestations of reasons for moving or derive from changes in other aspects of people's lives.

This article seeks to extend learning from the existing literature by investigating two relatively under-explored aspects in combination: (1) people's own experiences of well-being changes and perspectives on how these influenced moving decisions and (2) the implications of relocation for people's well-being in a range of domains, including those that did not feature among their reasons for moving. We used Sen's (2009) capability approach (CA) as a conceptual framework to support attention to the diverse aspects of well-being that can matter to people, and Massey's (1994) account of "place" for understanding relocation. We introduce these now. 


\section{Conceptual Framework of Capabilities and Place}

The CA is a framework for considering human well-being and equality. It can be combined with different social theories and has been developed and used in various ways (see Robeyns 2016 for an overview). At the core of all variants of the approach is the idea that if we want to examine the quality of people's lives, we need to attend to their capabilities (genuine freedoms and opportunities) for "valued functionings" (the kinds of things that people can be and do that are considered important for good human lives).

Several aspects of the CA make it useful for exploring experiences of relocation. It can give due recognition to the multidimensionality of well-being and to diversity in what matters to people. Although it is not always recognised, some key features of CA imply a relational ontology of capabilities (Smith \& Seward 2009). This means that capabilities should be understood not as fully embodied, internalised, and portable abilities, capacities or competences, but rather as relationally shaped freedoms or opportunities that depend in complex ways on interactions between individuals and the circumstances in which they live. The approach encourages recognition that capabilities are influenced by various social and spatial aspects of people's environments.

In the context of relocation, we envisaged that a focus on older people's valued capabilities could support engagement with what matters to them, exploration of how valued capabilities feature in relocation considerations, and generation of insights into their well-being across relocation trajectories.

The recognition that capabilities are situationally influenced can be fruitfully developed in conjunction with a complementary "relational" notion of place (Fleuret \& Atkinson 2007). Relational notions of "place" view it not as "mere locations with attributes" but, as socio-spatial contexts, simultaneously material and social, made through and by the relational linkages (Massey 1994).

These ideas encouraged us to conceptualise moving from one residence to another as a relational process rather than as two discrete events. They also reinforced our recognition that as people themselves change, their relationships to places are continually challenged and need to be negotiated - and that this has complex implications for decision-making about, and experiences of, staying or moving home (Cutchin 2001; Peace et al. 
International Journal of Ageing and Later Life

2011). Relational conceptions of capabilities and place helped us to view people's agency as situated, negotiated and expressed within social structures. As we explain below, a "capabilities" framework was useful for unpacking the implications of changing people-place relationships for well-being, and helpful both for understanding reasons for moving and evaluating experiences of moving.

\section{The Study Setting: Housing and Care Options in Scotland}

In Scotland, as in rest of the UK, approximately $91-93 \%$ of people aged 65 years and over live in conventional mainstream housing, $4-5 \%$ in supported housing and $3-4 \%$ in residential care homes (Office for National Statistics [ONS] 2013). Older adults in conventional mainstream housing are likely to be owner-occupiers (Department for Communities and Local Government [DCLG] 2015), with a smaller proportion living in social housing or private rented accommodation. Reflecting the emphasis on "ageing in place" (Scottish Government 2012), a range of services such as home adaptations, home and personal care are available, but needs-based thresholds for eligibility can restrict access to these.

Older adults can move into supported housing as a couple or individually. Supported housing is usually rented, mostly from housing associations and state agencies but also increasingly from the private sector (Harding et al. 2018). Availability varies across regions (Housing LIN 2019) but supply is generally low relative to demand (Local Government Association [LGA] 2017). For residential care homes, the state provides means-tested support towards costs, but increasing proportions of resident's self-fund the costs (almost 45\% according to Laing Buisson 2017). Couples may move in together if both are assessed as having care needs or if the relatively healthy partner can self-fund their stay.

\section{Methods}

This article reports one analysis from a broader qualitative interview study that explored older adults' experiences of living in diverse residential settings in Dundee, Scotland. The study sought particularly to understand how where people lived mattered for their well-being. The significance of moving residence, which is the focus of this article, became 
apparent during data generation and analysis, as 21 of the 26 study participants talked in some detail about their experiences of relocation. In this section, we first describe the methods used to generate data for the study overall and then explain the selection and analysis of data for this article more specifically. The study was approved by the University of Dundee Research Ethics Committee (approval number: UREC 12028).

\section{Eligibility, Recruitment and Consent}

People aged 60 years or above with sufficient cognitive and communicative capacity for an interview were eligible to participate in the study. We sampled purposively, seeking diversity in terms of participants' residential settings (owned or rented mainstream housing, supported and residential care settings) and socio-economic levels (two geographical locales in Dundee City designated most and least deprived in the Scottish Index of Multiple Deprivation).

To recruit older people living in mainstream housing, we visited lunch clubs, day care centres, local churches and carer centres. For people living in supported housing and residential care settings, we were helped by wardens and care managers who introduced us to residents based on study eligibility criteria. We asked people if they were willing to talk to a researcher about their life, what mattered to them for a good life, how where they lived affected what they could do or not, and likes and dislikes about where they lived. We offered opportunities to ask questions about the study and explained the voluntary nature of participation, that the interview would last for 1.5-2 hours and that they could stop or take a break if they wanted and have someone present for the interview if they wished. Those volunteering as a couple were given the option to be interviewed jointly or separately. We offered some scope for participants to choose when and where the interview would be held, explained that the interviews would be audio-recorded and transcribed, and that quotations would be anonymised for publication.

People were asked to indicate their willingness to participate by telephone, email, or face-to-face. Signed written consent or verbal recorded consent (for visually impaired participants) was obtained before interviews. 
International Journal of Ageing and Later Life

\section{Conduct of Interviews}

The interviews were all conducted by the first author, mostly at participants' place of residence, but four in day centres and one at a university office. Two heterosexual married couples chose to be interviewed jointly and one participant with a mild speech impairment invited a family member to support a smooth flow of conversation. Interviews lasted for approximately 2 hours.

Interviews were conducted conversationally, supported by a topic guide that reflected the conceptual framework of capabilities and place. Seeking to exploit the benefits of biographical approaches that "offer rich insights into the dynamic interplay of individuals and history, inner and outer worlds, self and other" (Merrill \& West 2009: 1), we opened the interviews by asking participants "tell me about yourself and your life?" This helped us to locate what participants said about their current and recent experiences, including of where they were living, within the broader contexts of their whole lives. A biographical approach facilitated the understanding of why people valued some things differently over time.

Next, we asked participants open-ended questions about the kinds of things that mattered to them. Drawing on Finnis (1980) we included prompts, if required, to consider domains of life/health/security, friendships, work and play, self-expression, religion/spirituality and knowledge. We encouraged participants to explain why something mattered to them. To investigate the implications of place for participants' well-being, we asked explicitly how where they lived made a difference to their opportunities to enjoy what mattered to them. For example, if relationships mattered, "how does living here make it easier or harder for you to maintain and form relationships?." We did not use the word "capabilities" relying instead on conversational questions about what participants valued being able to do and whether and how where they lived helped or made it difficult to do those things.

\section{Data Analysis}

Data analysis involved five iterative stages of the Framework Approach (Ritchie \& Lewis 2003): familiarisation, identifying a framework, indexing, charting, and mapping and interpretation. All authors read a sample of 
transcripts. The first author became more closely familiar with the whole data set. Paying close attention to participants' accounts our analysis was also guided by the research questions and well-being domains covered in the topic guide. For each of the six well-being domains derived from Finnis (1980) we developed a set of four low-level descriptive analytic categories to organise the data: "what matters," what participants were "able to do," "what participants were not able to do," and "how where they lived (current and previous places) made a difference." This allowed us to examine how current and previous places of residence featured in accounts of valued aspects of participants' lives.

Once the analytic categories were agreed through discussion, the first author worked systematically through all transcripts to apply them to the data (indexing), then summarised the indexed data and noted key quotes into charts, with columns describing the key framework categories and rows representing individual interviewees (charting). The first author took primary responsibility for interpretation, using the column and row arrangements to look for patterns and contradictions within and across cases, re-reading complete transcripts to maintain familiarity with whole individual stories. The charted data and a selection of interviews were reviewed by co-authors to support critical discussions of data interpretation and to develop analyses of what mattered for well-being and how well-being was tied to place, including through relocation. As joint interviewing was not deliberately built into the data collection strategy, following Öhlén et al. (2006), we analysed accounts of each partner separately.

\section{Data Sample}

We interviewed a diverse sample of 26 people between 65 and 96 years of age. Here we focus on 21 participants who discussed at least one relocation. Table 2 summarises participants' socio-demographic characteristics, including living arrangements at the time of interview. Table 3 summarises the types and timing of the moves they spoke about. While three participants had moved more than once, our analysis is limited to the most recent moves. 
International Journal of Ageing and Later Life

Table 2. Socio-demographic profile of participants

\begin{tabular}{|c|c|c|}
\hline & $\begin{array}{l}\text { Participants who } \\
\text { relocated at least } \\
\text { once }(n=21)\end{array}$ & $\begin{array}{l}\text { Participants } \\
\text { (total study sam- } \\
\text { ple) }(n=26)\end{array}$ \\
\hline \multicolumn{3}{|l|}{ Sex } \\
\hline Male & 9 & 10 \\
\hline Female & 12 & 16 \\
\hline \multicolumn{3}{|l|}{ Age } \\
\hline $65-74$ & 4 & 4 \\
\hline $75-84$ & 9 & 13 \\
\hline $85+$ & 8 & 9 \\
\hline \multicolumn{3}{|c|}{ Relationship status (at time of interview) } \\
\hline Married & 4 & 7 \\
\hline Widowed & 15 & 17 \\
\hline Never married & 1 & 1 \\
\hline Divorced & 1 & 1 \\
\hline \multicolumn{3}{|l|}{ Living arrangements } \\
\hline Alone & 17 & 19 \\
\hline With spouse & 4 & 7 \\
\hline \multicolumn{3}{|l|}{ Setting } \\
\hline Mainstream housing & 4 & 9 \\
\hline $\begin{array}{l}\text { Sheltered \& Very sheltered } \\
\text { (Supported housing) }\end{array}$ & 8 & 8 \\
\hline Residential Care homes & 9 & 9 \\
\hline \multicolumn{3}{|c|}{ Self- reported health conditions/impairments } \\
\hline With conditions & 18 & 24 \\
\hline No conditions & 3 & 2 \\
\hline \multicolumn{3}{|l|}{ Previous occupation* } \\
\hline Professional/managerial & 4 & 6 \\
\hline Intermediate & 4 & 7 \\
\hline Routine and manual & 11 & 11 \\
\hline Never worked & 2 & 2 \\
\hline \multicolumn{3}{|c|}{ Deprivation status of current neighbourhoods } \\
\hline Least deprived & 8 & 11 \\
\hline Most deprived & 13 & 15 \\
\hline
\end{tabular}


Moving residence in later life

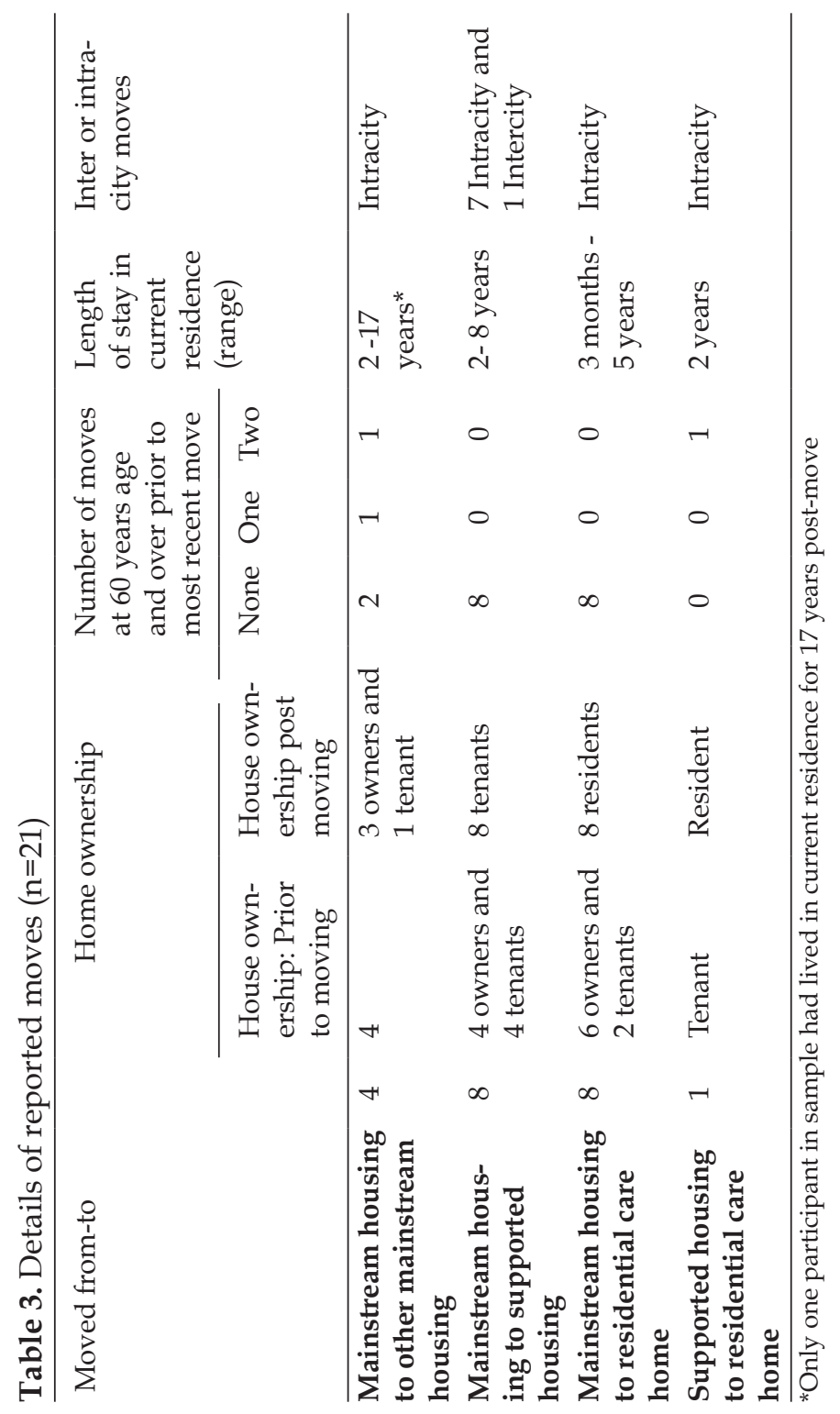


International Journal of Ageing and Later Life

\section{Findings}

Participants' accounts revealed a diverse array of capabilities that mattered for their well-being and illuminated the role of place in shaping those. Our analysis is presented under two main headings, with sub-headings as outlined in Table 4. The first section, "Restoring or securing capabilities," provides an account of participants' changing relationships with where they lived and how those shaped relocation considerations and decisions. The second section, "Capability changes experienced," explores the implications of moving. We have selected examples from across the social spectrum to illustrate some of the different circumstances surrounding people's moves.

\section{Restoring or Securing Capabilities}

We summarise participants' accounts of what prompted them to move or consider moving residence under two headings: "Why move?: risks to multiple capabilities" and "Moving where?: considerations and constraints on options." In both cases, we consider moves between different kinds of setting.

Table 4. Themes and sub-themes

\begin{tabular}{ll}
\hline $\begin{array}{l}\text { Restoring and securing } \\
\text { capabilities }\end{array}$ & Why move? risks to multiple capabilities \\
& $\begin{array}{l}\text { Moving where? considerations and con- } \\
\text { straints on options }\end{array}$ \\
\hline Capability changes experienced & $\begin{array}{l}\text { Expanded } \\
\text { Capabilities that already existed and could be } \\
\text { realized but have now been augmented/enhanced }\end{array}$ \\
& $\begin{array}{l}\text { Reduced } \\
\text { Capabilities diminished or lost }\end{array}$ \\
& $\begin{array}{l}\text { Newly acquired } \\
\text { Capabilities difficult to achieve in previous set- } \\
\text { ting or become available upon moving }\end{array}$ \\
Intact \\
Capabilities not impacted by the move
\end{tabular}


Moving residence in later life

\title{
Why Move?: Risks to Multiple Capabilities
}

The loss, or anticipated loss, of scope to do what mattered to them or to maintain valued identities was the main underlying motivation in accounts of relocation. We can thus interpret many reasons for (considering) moving as attempts to restore or secure diminished or "at risk" capabilities for valued functionings. These related, in broad terms, to daily life within and beyond participants' place of residence, and particularly to caring and ensuring support for care for themselves and/or a spouse.

A substantial majority of participants highlighted diminishing capabilities to get around inside their home; get outside into gardens; go beyond the home; and, so, to manage other interlinked capabilities, such as shopping and/or participating in social and community life. These valued capabilities were circumscribed by varying interactions of material features of place (e.g. steps, a lack of lifts and narrow doors) and restrictions of bodily movement associated with health conditions, as evident in the following quote:

\begin{abstract}
I had two heart attacks, quadruple bypass and that is when I had my stroke, when I came out of the bypass. I sold it [apartment] when I got unwell because I could not climb stairs very well. The doctors said I should not be climbing stairs. There were about 36 stairs to climb before you got to your front door and health people, social services put up bannisters for me going up because I could not take it[...] the wife has got COPD [a respiratory condition] very very bad. She was finally struggling up the stairs, came with all the messages [shopping] and it was far too much [...] We weren't going out [...]we were staying in a lot.

(Henry, 73 years, lives with spouse, domestic setting)
\end{abstract}

Participants, particularly those living in less affluent or higher crime areas also described threats to other valued capabilities including to be and feel safe from intruders, avoid anxiety about something untoward happening, live in a safe environment and sleep well. Features of the local neighbourhood could undermine several capabilities, directly and indirectly, as shown in the below quote:

I had a drug dealer across the door from me, a drug dealer down the stairs [...]. I used to get my bell rung, drug addicts on stairs all night, sometimes I get my bell ringing 2, 3 or 4 in the morning or knocking on my door thinking I was selling drugs. I could not really go out, because if I went out I was frightened my house would be broken into.

(Darren, 67 years, separated, very sheltered setting) 
International Journal of Ageing and Later Life

Some participants reported significant changes in their neighbourhoods over time. When neighbourhood deterioration coincided with their own ageing and health-related changes, it could exacerbate the impact of these on a cluster of valued capabilities:

\begin{abstract}
I moved here [very sheltered setting] because I had arthritis in my knees. Stairs were starting to get on my nerves, I was in too much pain [...] I did not mind being on my own [after husband's death] but sometimes I did. I felt the part where I lived [previously] there seemed to be a lot of people coming, drunks, drugs and you would see them staggering along and everything. It never used to be like that, but it is quite common now. I was scared on my own, I used to hear noise in the street and you would not believe, I had a poker under my bed. You see, you just stepped into my house from the outside, the door was on the street.
\end{abstract}

(Cathy, 81 years, widow, very sheltered setting)

For a couple of participants, moving was primarily a way to secure capabilities that had been affected by personal life events and further impacted by issues of place. For example, being widowed could limit the scope for participation in meaningful personal relationships, avoiding loneliness and getting out and about, and these capabilities might be further impaired by the altered experience of a home without the life partner with whom it was previously shared:

It's just that I wasn't going out. I was keeping well enough but I just didn't want to go out, I was in the house most of the time [...] I worried my family to death because I wasn't going out. She [daughter] is in [South England] and my son is in [another Scottish city]. I had home help coming in.

(Tina, 84 years, widow, care setting)

Concern to secure capabilities to access prompt attention and care motivated several couples to consider moving. This was particularly striking in situations in which both partners had developed health problems with similar implications (e.g. proneness to falling). Concerns about the limited availability of support in their current settings were often reinforced by family members, as shown in the following quote:

I have multiple sclerosis [...] Well I was looking after my wife and I fell twice in the house in one day, that was enough really [...] if both of us fall at the same time, we would really be in a stew. And the family said, "you are not safe living here, what if you both fall at the same time?," which could have happened. We had an alarm system 
to the sheltered housing complex and they had come in and make sure you were okay. Half the time I was still lying in the same position when they came in. I just could not get up. [In residential care home] I feel a lot safer to be honest.

(Stuart, 81 years, interviewed with Sara, 78, residential care setting)

Scope to secure "at risk" capabilities in situ could depend on a combination of personal and broader considerations, including health conditions, housing design, the expense and scale of work involved in potential modifications, personal resources and connection to place.

\section{Moving Where?: Considerations and Constraints on Options}

All participants had sought, with their moves, to restore or secure several valued but diminished or "at risk" capabilities for themselves or a spouse. The question of where to move to was rarely simple. Some potential new locations were likely to enhance some valued capabilities but restrict others, so decisions about whether and where to move involved trade-offs. For a few, the kind of moves they first considered were, on further examination, rendered less feasible by limited financial resources, lack of access to necessary supports (sometimes due to ineligibility), or the wishes of significant others. The emphasis within the many considerations in each participant's account varied. The first two quotations below both reflect some emphasis on the need to meet the health-related support needs of a spouse:

I wanted to stay with [wife], be together and that was it. I'd have rather stayed in our house, but it was impossible [...] you couldn't cope on your own, which I knew I couldn't because on many occasions, I had to phone my son and tell him to come down right away. I couldn't handle it. She was getting too aggressive [...] we had accommodation for a couple of nurses if we wanted, but it would be very expensive to do that [...] social services said you'd really have to get a live-in nurse [...]. So, I had it all planned out that we were going to buy a sheltered house and at least we would have a warden there and we wouldn't be on our own, but they [social services] said that that just couldn't be. I sold the house.

(Benny, 90 years, lives with spouse with Alzheimer's disease, residential care setting)

I was very lucky that I only fell ill once, and I could not have sat in bed because he [husband] had appointments to go to. [...] you begin to realise that - what if anything happens to me? You worry what is going to happen to him. We needed, I felt we needed a backup [...] I haven't got any relatives at all because I am only child and so is he [...] 
International Journal of Ageing and Later Life

\begin{abstract}
My daughter lives down in London and my son lives in [Europe]. To let you understand my daughter has not had anything to do with us for a long time. I know a lot of people say, "Oh no, I wouldn't sell my flat" but it was a case of either we stayed there and have no life because to get out was such an ordeal.
\end{abstract}

(Rita, 80 years, widow, sheltered setting)

Co-resident couples, however, did not always share the same thoughts about moving. Peter suffered physical and speech impairments following a stroke. His daughter-in-law explained that Peter's wife had initially been reluctant to move from their upstairs flat, although this hugely limited Peter's capability to get out and about and participate in social and community life. In this case, adult children apparently influenced the decision to move:

\begin{abstract}
Daughter-in-law: Peter found it difficult to get out and about. [To Peter] You tell me if I am wrong. When you were at [previous upstairs apartment] you spent your day at the window watching the world go by. His wife was obviously doing all the looking after for him. My husband and I used to try and persuade them to move but his wife always said no, not moving [...] eventually we managed to persuade her.
\end{abstract}

(Peter, 72 years, widower, domestic setting)

For a couple of participants, especially those living alone after being widowed, securing capabilities for affiliation was paramount in their choice of where to move. Some purchased another property in a locality that they had grown up in, knew and liked, maintaining closeness to friends or adult children. Others chose to move into a supported housing to meet new people. Tina, who valued being around other people and had become unhappy living alone following her husband's death, self-funded a move into a local residential care setting although this was not (yet) necessary for health reasons:

[In the care home] I have company and I have good friends and staff are super [...] I usually go down in the lounge, there is usually somebody.

(Tina, 84 years, widow, residential care setting)

Unlike others, Darren did not indicate a desire to move into a specific setting or neighbourhood. He was unique in our sample in having neither the financial resources nor (initially) support from statutory services to follow through his preferences to leave a setting where he lacked several 
key capabilities. It was 11 years before his health deteriorated to a point that he became eligible for support and was able to move into very sheltered accommodation:

I could not get help from council; nobody wanted to help me. I wanted moving and they [Council staff] were not interested; I just gave up in the end. What was it, 2008, I completely lost the use of my legs for four days and from then I got really bad, I could not walk, could not get up the stairs [...] I went to social services and I was crying. I told them I had to be moved because I was too ill [...] and this is how I got in here.

(Darren, 67 years, separated, very sheltered setting)

\section{Capability Changes Experienced}

Although moves were largely motivated by concerns to restore or secure particular, valued capabilities, participants' accounts suggest that relocation impacted several other valued capabilities as well. As summarised in Table 5, previous or existing capabilities could be "expanded," "reduced" or remain "intact," and sometimes "new" capabilities were acquired with a move. Participants experienced different combinations of capability changes with their moves, and various features of place at different scales of the settings they moved to (e.g. care home room, garden, neighbourhood and wider locality) were implicated in these changes.

\section{Expanded Capabilities}

Most participants reported some enhancements or augmentation of capabilities they already possessed. The kinds of capabilities enhanced by a move were diverse. Participants explained, for example, how a chapel within a residential care home increased their opportunities to attend church services, and how bus services between their sheltered accommodation and a supermarket made it easier to get out and procure daily necessities. Joe, who had maintained a stamp collection in his previous residence, found a more peaceful environment enabled him to engage more fully with his hobby:

[In new residence and surrounding environs] it is quiet, there is no rowdy kids going about which is a godsend for my hobby because I don't like getting distracted when I am doing it. For my stamp hobby, I also do coins. It used to be rowdy where I used to stay before, teenagers and all, near the shops.

(Joe, 65 years, widower, sheltered setting) 
International Journal of Ageing and Later Life

Table 5. Examples of Capability changes by individual participants

\begin{tabular}{|c|c|c|c|}
\hline & $\begin{array}{l}\text { Peter (main- } \\
\text { stream } \\
\text { to other } \\
\text { mainstream } \\
\text { housing) }\end{array}$ & $\begin{array}{l}\text { Diane (mainstream to sheltered } \\
\text { housing) }\end{array}$ & $\begin{array}{l}\text { Sara and Stuart } \\
\text { (mainstream } \\
\text { housing to resi- } \\
\text { dential care home) }\end{array}$ \\
\hline $\begin{array}{l}\text { Rea- } \\
\text { sons for } \\
\text { moving } \\
\text { residence }\end{array}$ & $\begin{array}{l}\text { To be able } \\
\text { to get out } \\
\text { and about of } \\
\text { their upstairs } \\
\text { flat follow- } \\
\text { ing a stroke } \\
\text { as stopped } \\
\text { going out } \\
\text { due to the } \\
\text { difficulty in } \\
\text { negotiating } \\
\text { stairs. }\end{array}$ & $\begin{array}{l}\text { To access good quality treatment } \\
\text { for her husband who had Alzhei- } \\
\text { mer's and having a granddaugh- } \\
\text { ter in Dundee who worked in } \\
\text { the health care system prompted } \\
\text { Diane and her husband to make } \\
\text { the move from another city }\end{array}$ & $\begin{array}{l}\text { To feel safe and } \\
\text { secure and reduce } \\
\text { the constant anx- } \\
\text { iety about the im- } \\
\text { plications of both } \\
\text { partners falling at } \\
\text { the same time due } \\
\text { to their respective } \\
\text { health conditions. }\end{array}$ \\
\hline $\begin{array}{l}\text { Direc- } \\
\text { tion of } \\
\text { capa- } \\
\text { bility } \\
\text { change }\end{array}$ & $\begin{array}{l}\text { Peter (main- } \\
\text { stream } \\
\text { to other } \\
\text { mainstream } \\
\text { housing) } \\
\text { description } \\
\text { of change } \\
\text { and quote }\end{array}$ & $\begin{array}{l}\text { Diane (mainstream to sheltered } \\
\text { housing) } \\
\text { description of change and quote }\end{array}$ & $\begin{array}{l}\text { Sara and Stuart } \\
\text { (mainstream } \\
\text { housing to resi- } \\
\text { dential care home) } \\
\text { description of } \\
\text { change and quote }\end{array}$ \\
\hline Expanded & $\begin{array}{l}\frac{\text { None ob- }}{\text { viously }} \\
\text { mentioned }\end{array}$ & $\begin{array}{l}\text { Being able to participate more } \\
\text { fully in the life of her great } \\
\text { grandchildren } \\
\text { One of the reasons why I would } \\
\text { like to stay here is I would like } \\
\text { to see my great grandchildren } \\
\text { growing up as well. }\end{array}$ & $\begin{array}{l}\frac{\text { Being able to prac- }}{\text { tice religion daily }} \\
\frac{\text { (Sara and Stuart) }}{\text { We get to church }} \\
\text { everyday which } \\
\text { is a plus isn't it? } \\
\text { (Sara) }\end{array}$ \\
\hline
\end{tabular}

(Continued) 
Table 5. (Continued)

\begin{tabular}{|c|c|c|c|}
\hline $\begin{array}{l}\text { Direction } \\
\text { of ca- } \\
\text { pability } \\
\text { change }\end{array}$ & $\begin{array}{l}\text { Peter (main- } \\
\text { stream } \\
\text { to other } \\
\text { mainstream } \\
\text { housing) } \\
\text { description } \\
\frac{\text { of change }}{\text { and quote }}\end{array}$ & $\begin{array}{l}\text { Diane (mainstream to sheltered } \\
\text { housing) } \\
\text { description of change and quote }\end{array}$ & $\begin{array}{l}\text { Sara and Stuart } \\
\text { (mainstream } \\
\text { housing to resi- } \\
\text { dential care home) } \\
\text { description of } \\
\text { change and quote }\end{array}$ \\
\hline Reduced & $\begin{array}{l}\frac{\text { None ob- }}{\text { viously }} \\
\text { mentioned }\end{array}$ & $\begin{array}{l}\text { Being able to enjoy other valued } \\
\text { social relationships and frequent } \\
\text { social interaction; Being able to } \\
\text { live in a familiar environment My } \\
\text { life is much wider from where I } \\
\text { come. We did not have a family } \\
\text { there [previous place of residence] } \\
\text { but we lived there for many years, } \\
\text { lots of friends. I am lucky to have } \\
\text { the kind of people as friends that } \\
\text { keep in touch with phone calls or } \\
\text { letters that I do keep in touch and } \\
\text { that but it is not the same } \\
\text { Being able to live in spacious } \\
\text { accommodation } \\
\text { We had a fairly-large home [...] } \\
\text { [Two bedroom] we had a kitchen, } \\
\text { dining room and I had taken this } \\
\text { place unseen. My daughter and } \\
\text { granddaughter, they viewed it, } \\
\text { arranged for carpeting and all. } \\
\text { And I brought [...] no dining table } \\
\text { or anything like that. I knew that } \\
\text { there would no space and just } \\
\text { about enough space for meals and } \\
\text { watching TV. I wondered where I } \\
\text { would do the ironing [...] because } \\
\text { by the time you got the ironing } \\
\text { board up, it was more in the } \\
\text { bedroom }\end{array}$ & $\begin{array}{l}\text { Being able to do } \\
\text { specific household } \\
\text { related chores } \\
\text { (Sara) It is people } \\
\text { doing things for } \\
\text { you that you had } \\
\text { rather do yourself. } \\
\text { In the house we } \\
\text { had our tea, and } \\
\text { then we would } \\
\text { say we will do the } \\
\text { dishes now so that } \\
\text { we can sit together } \\
\text { and watch the } \\
\text { news, so I liked } \\
\text { that part, whereas } \\
\text { here, they come } \\
\text { and take away } \\
\text { your cup and it is } \\
\text { washed [...] (Sara) }\end{array}$ \\
\hline
\end{tabular}


International Journal of Ageing and Later Life

Table 5. (Continued)

\begin{tabular}{|c|c|c|c|}
\hline $\begin{array}{l}\text { Direction of } \\
\text { capability } \\
\text { change }\end{array}$ & $\begin{array}{l}\text { Peter (mainstream } \\
\text { to other main- } \\
\text { stream housing) } \\
\text { description of } \\
\text { change and quote }\end{array}$ & $\begin{array}{l}\text { Diane (main- } \\
\text { stream to sheltered } \\
\text { housing) } \\
\text { description of } \\
\text { change and quote }\end{array}$ & $\begin{array}{l}\text { Sara and Stuart } \\
\text { (mainstream to care } \\
\text { home) } \\
\text { description of } \\
\text { change and quote }\end{array}$ \\
\hline $\begin{array}{l}\text { Newly } \\
\text { acquired }\end{array}$ & $\begin{array}{l}\text { Being able to do } \\
\text { things confidently } \\
\text { on his own } \\
\text { If I want to do any- } \\
\text { thing I could just } \\
\text { go ahead and do it } \\
\text { (Peter). } \\
\text { Normally I would } \\
\text { go with Peter to } \\
\text { the hospital for } \\
\text { appointments. I } \\
\text { was working night } \\
\text { shift last week and } \\
\text { Peter had to go for } \\
\text { diabetic screening } \\
\text { clinic at nine in } \\
\text { the morning. So } \\
\text { he said, 'I will go } \\
\text { myself'. So he took } \\
\text { the bus, did his } \\
\text { appointment and } \\
\text { came back again, } \\
\text { which he would } \\
\text { not have done } \\
\text { before. [Previous } \\
\text { apartment] It was } \\
\text { only one floor up } \\
\text { but two flights of } \\
\text { stairs but Peter } \\
\text { found it difficult to } \\
\text { get out and about. } \\
\text { (Daughter in law) }\end{array}$ & $\begin{array}{l}\text { Being able toaccess } \\
\text { family support and } \\
\text { care if needed } \\
\text { She [granddaugh- } \\
\text { ter] said but what } \\
\text { happens if you } \\
\text { get ill? Well I can't } \\
\text { really do anything } \\
\text { if I get ill you } \\
\text { know[..] I have got } \\
\text { good friends [in } \\
\text { Aberdeen] but I } \\
\text { can't expect them } \\
\text { to keep, take care } \\
\text { of me when I get } \\
\text { ill. So she said, I } \\
\text { should think about. } \\
\text { And I decided I } \\
\text { would stay put [in } \\
\text { Dundee] }\end{array}$ & $\begin{array}{l}\text { Being able to par- } \\
\text { ticipate in social/ } \\
\text { health activities } \\
\text { (Sara and Stuart) } \\
\text { We come down to } \\
\text { the lounge and join } \\
\text { in with everybody } \\
\text { on what is going } \\
\text { on. And we had } \\
\text { the physio lady } \\
\text { today, so we did all } \\
\text { the exercises and I } \\
\text { don't actually mind } \\
\text { the physio, it is for } \\
\text { your own good [...] } \\
\text { and then a lady that } \\
\text { comes in she, what } \\
\text { does she do (to her } \\
\text { husband) (Sara). } \\
\text { Reminiscing, so } \\
\text { everybody joins in } \\
\text { and it is quite inter- } \\
\text { esting. (Stuart). }\end{array}$ \\
\hline
\end{tabular}

(Continued) 
Moving residence in later life

Table 5. (Continued)

\begin{tabular}{|c|c|c|c|}
\hline $\begin{array}{l}\text { Direction of } \\
\text { capability } \\
\text { change }\end{array}$ & $\begin{array}{l}\text { Peter (mainstream } \\
\text { to other main- } \\
\text { stream housing) } \\
\text { description of } \\
\text { change and quote }\end{array}$ & $\begin{array}{l}\text { Diane (main- } \\
\text { stream to sheltered } \\
\text { housing) } \\
\text { description of } \\
\text { change and quote }\end{array}$ & $\begin{array}{l}\begin{array}{l}\text { Sara and Stuart } \\
\text { (mainstream to care }\end{array} \\
\text { home) } \\
\text { description of } \\
\text { change and quote }\end{array}$ \\
\hline & $\begin{array}{l}\text { Being able to partic- } \\
\text { ipate in social life of } \\
\text { community } \\
\text { [...] Before when } \\
\text { you [to Peter] were } \\
\text { in Dundee you did } \\
\text { not go out whereas } \\
\text { here he is definitely } \\
\text { taking part, he talks } \\
\text { to all these women } \\
\text { who live around } \\
\text { here, chats to the } \\
\text { window cleaner } \\
\text { [Peter nods]. [When } \\
\text { Peter and his wife] } \\
\text { the two of them } \\
\text { sat outside on their } \\
\text { deck chairs [new } \\
\text { apartment] and } \\
\text { they got to know } \\
\text { everybody [Daugh- } \\
\text { ter in }\end{array}$ & & $\begin{array}{l}\text { Freedom from } \\
\underline{\text { household chores }} \\
\frac{\text { (Stuart) }}{\text { Yeah, I have no }} \\
\text { cleaning do here at } \\
\text { all [in care home] } \\
\text { (and laughs). It is } \\
\text { great...' (Stuart) }\end{array}$ \\
\hline Intact & $\begin{array}{l}\text { Being able to con- } \\
\text { tinue being a home } \\
\text { owner } \\
\text { Yes, [owned the } \\
\text { apartment] in B. } \\
\text { street and this one. }\end{array}$ & $\begin{array}{l}\text { None obviously } \\
\underline{\text { mentioned }}\end{array}$ & $\begin{array}{l}\text { Being able to see } \\
\text { family (Sara and } \\
\text { Stuart) } \\
\text { Sara: It [Seeing } \\
\text { family] has not } \\
\text { changed an awful } \\
\text { lot, the two boys } \\
\text { are in Glasgow and } \\
\text { they come through } \\
\text { every fortnight } \\
\text { don't they. [Three } \\
\text { daughters come up] } \\
\text { every night (Sara) }\end{array}$ \\
\hline
\end{tabular}


International Journal of Ageing and Later Life

\section{Reduced Capabilities}

People who had moved to supported and residential care settings sometimes experienced unanticipated reductions in valued capabilities, including to engage in some daily household activities (e.g. do one's own ironing), to have room to do things in one's private space, and to express valued identities (e.g. by personalising rooms). The negative experiences of these reduced capabilities were perhaps exacerbated for people who had been less able to participate in decisions about their move:

\footnotetext{
I was in hospital quite a wee while and my daughter had gone around looking at all homes. In the other house, sheltered housing, we had our own furniture. When we came in here, [daughter] says, mum you do not need furniture, you have to get rid of that, it is all furnished up. And she thought it was fine. I didn't really like that [...] Well, you are in a wee room, you know and you feel constricted. I miss the table, I always like a table to sit at and do things.
}

(Sally, 86 years, widow, residential care setting)

Moves that enhanced particular capabilities for some participants did not do so for others. Notably, one participant who moved into sheltered accommodation experienced difficulties in forming new social relationships despite her willingness to be sociable. She had moved from another city a year ago to secure better healthcare for her husband but her lack of familiarity with Dundee and lack of shared social identity with other residents limited her scope to find common ground in social interaction:

Seventy-five per cent of the people here come from Dundee and few of them from the Ferry. This is where they were born, brought up, went to school. And so if you have a group such as this on a Friday morning, [...] that is what they talk about. I don't belong here. It doesn't mean anything for us and I suppose it would be easier if we belonged either in Dundee or the Ferry. I have not changed countries or anything like that. But it is very different. Simply because the people are very different.

(Diane, 79 years, widow, sheltered setting)

Reductions in some capabilities mattered more to some people than other. While some participants who had previously owned homes did not comment negatively about their change in ownership status when they sold up, one found the loss of his capability to identify as a house owner difficult: 
I mean when you have got your own house for 20 odd years and you have to sell it, is a big comedown for me, because it was a bit of pride for me, owning my own house [...] and I could not afford to buy a brand-new bungalow.

(Henry, 73 years, lives with spouse, domestic setting)

\section{Newly Acquired Capabilities}

Participants often also acquired new capabilities following a move. A couple of participants who had previously relied on meals-on-wheels services in domestic homes or supported housing remarked how the move to residential care generated capabilities to choose what to eat, to enjoy regular, appetising meals in a sociable setting, and so to be well nourished and engage in more personal care:

[At previous residence] you were getting your food handed in and things like that [meals on wheels]. And the food was there, if you didn't like it, what happens, you didn't eat it. But here, if you say "oh, I don't want that," they say, "would you like a sandwich? Would you like this?" You get a choice, but, I mean, they were coming to your door [at previous residence] there was your food and it was a case of, if you didn't like it, what happened?

(Peggy, 89 years, widow, residential care setting)

When I first came here [residential care home] I was not strong; I had lost all weight, I had to get help to go from bed to chair and likewise to the toilet. That was annoying me because you wanted to do that for yourself but as you are well fed here and as I put on weight I got the strength I was able to do these things. That was a big thing and when eventually managed to do that that was fine.

(Sally, 86 years, widow, residential care setting)

For others, material and social features of their new residence (e.g. a garden, a quiet and safe neighbourhood, organised activities, supported exercise opportunities and the quality of interaction with staff) helped to generate capabilities to enjoy valued activities and feel relaxed or less stressed:

The bungalow it encouraged me to sit outside because we bought deck chairs and umbrellas, well, we did not have that in the other house. The other thing is it is awfully quiet here [neighbourhood] whereas round at the other house it was awfully noisy, police were never out of the street. So in one way I was glad to get out. Where I am now I find I can relax more even though there are kids running about, you can put up with that but I can relax more, I can be more of myself.

(Henry, 73 years, lives with spouse, domestic setting) 
International Journal of Ageing and Later Life

\section{Intact Capabilities}

A substantial majority were actively involved in choosing what kind of setting or locality to move into (all but one moved locally) and mentioned some capabilities that remained relatively stable following a move. These included capabilities to live in spacious accommodation, familiar neighbourhoods or a home city; engage in valued activities beyond their home (e.g. watching football or bowling); and enjoy valued social relationships (e.g. be visited by family):

We were brought up in a tenement [apartment] and we lived on third floor and then we lived in multi [storeyed apartments] and I did not want any on ground floor. There was an empty flat downstairs [in current apartment block] with a lovely new carpet. I mean I could have taken that but it was not as big as this one. I wanted up high and I like space. (Tara, 89 years, widow, very sheltered setting)

For a few, the absence of some valued capabilities also persisted after a move. That the "intact capability" label can also apply to valued-but-missing capabilities is exemplified by Jim, whose wife had died recently and who saw his scope to be happy as largely dependent on that unchangeable fact:

Jim: I was living on my own and not very happy with it, coming here it didn't change it that much, wasn't that drastic a change.

Interviewer: And what would happy be, if you could do something about it?

Jim: Bring my wife back

(Jim, 82 years, widower, residential care setting)

To illustrate the different combinations of capability changes that could be experienced on relocation, Table 5 summarises the changes mentioned by three individual participants.

\section{Discussion}

Our study has identified concerns to secure valued capabilities as a key motivation for relocation by older adults. It has illustrated the challenging nature of relocation decisions, highlighting requirements for "trade-offs" 
when multiple valued capabilities (including those of co-habiting partners) are "at risk" and are likely to be variously impacted by decisions to stay or move to different kinds of residence. It has also illuminated the diverse ways in which well-being, understood in terms of having capabilities for valued functionings, can influence and be impacted by relocation in later life.

Our analysis reflects and evidences the complex implications of moving for the well-being of older adults. By conceptualising moving out and moving in as part of the same dynamic process, working with relational conceptions of capabilities and place, and using a qualitative and biographical approach, we have been able to contribute to the literature on relocation in later life in three distinct ways. Firstly, our findings demonstrate that several capabilities over and above those that feature as reasons for moving can be impacted by relocation. Secondly, we have shown how reported changes in well-being can derive from different combinations of changes in other aspects of people's lives (which reinforce the importance of understanding relocation as a process that unfolds through dynamic contexts). Thirdly, recognition of the various ways in which capabilities might change can serve as a conceptual/analytical heuristic to progress thinking about the implications of relocation in ways that can avoid the limitations of both simple binaries of positive and negative experiences and narrow views of activities of daily living.

Confirming the significance of place for well-being, our findings offer a useful reminder to adopt richer conceptions of place (Massey 1994). We note that sustaining some capabilities, for example, to develop new social relationships, can be more difficult and time consuming where an older person moves to an unfamiliar city.

\section{Study Limitations}

This study was not designed to focus on relocation: the significance of relocation emerged during interviews. Although there was considerable diversity in the kinds, number and timing of moves participants talked about, and in the reported well-being implications of moving, some moves had happened a while ago. This raises questions of recall quality and may have shaped the reporting of some capability changes. However, as our findings also illustrate, some capabilities develop over time 
International Journal of Ageing and Later Life

(e.g. new social relationships) and complex relational dynamics can lead people to re-evaluate the kind of capabilities and place(s) that matter for well-being over time. A prospective study on relocation could have sampled and probed to investigate these possibilities.

Relatedly, although our biographical approach and foregrounding of the dynamic nature of people-place relationships allowed generation of useful insights, we have not examined the influence of multiple moves. Some research suggests that people who move often acquire environmental skills to adapt (Rowles \& Watkin 2003). Future research could be designed to consider the implications of multiple moves (Peace et al. 2006).

As with all research, our methodological choices have implications, not all of which can be fully known. We deliberately gave participants a choice to be interviewed alone, jointly with their partner, or in the presence of a significant other. We were careful in joint interviews to ensure both interviewees' voices and stories were captured, but both the offer of choice and the interview process are complex and include potential for harm through disclosures (Polak \& Green 2016). We were not aware of any tension or discomfort during joint interviews, but we did not analytically address couple interactions alongside personal accounts.

\section{Contributions to Theoretical Development}

Despite the limitations, our diverse sample and our approach to data generation and analysis (qualitative, biographical design and use of relational conceptions of capabilities and place) allowed us to overcome some of the limitations of studying decisions to move and experiences of moving separately. They generated rich insights into the complexity and variability of relocation trajectories and experiences, going well beyond the considerations explicitly supported by the theoretical models that have guided academic work in this field to date.

For example, our findings illustrate a diversity in trajectories of moves into different settings that is not adequately reflected in Litwak and Longino's (1987) typology. Each move was influenced by some unique combination of the capabilities a person (or couple) valued, the ways in which those capabilities were constituted or threatened by their personal embodiment and social environment, and the feasibility of different housing alternatives for them. This should encourage researchers and policy 
leaders to resist the temptation to assume that some kinds of situation or life event inevitably necessitate or render appropriate particular kinds of move. Declining health or widowhood, for example, did not always trigger moves into residential care setting or supported housing, and such moves did not have consistent implications for people's well-being.

The CA encouraged consideration of the plural and open-ended nature of what matters for well-being. This supported identification of a wide range of freedoms and opportunities that mattered to participants, again challenging the value of the more reductionist, deficit-focused approaches that can be fostered by Lawton's (1977) consideration of competences. Deficits in competencies featured as some of what could contribute to scope to do things or live in ways that were ultimately important for well-being. Our primary focus on capabilities is consistent with a growing recognition that these are significant and salient for the study of well-being in older adults (Grewal et al. 2006; Jansen et al. 2017).

While broadly reinforcing Lawton's recognition of the significance of people-place interactions, our approach permits richer ecological insights into person-place interactions in two ways. Firstly, our findings captured and reinforced recognition of the relational and social components of interactions beyond personal competencies and physical environment (Cutchin 2001). Secondly, we also highlighted the dynamic, situated and variable interactions of life events with place, showing, for example, how a loss of spouse may threaten someone's capability to avoid loneliness or manage unexpected changes in everyday life, perhaps especially when living in a deprived neighbourhood or experiencing health problems. Our analyses demonstrated the dynamic and complex (hence not entirely predictable) production of capabilities via person-place interactions - confirming the need to consider place and person holistically and relationally.

Our findings also support previous challenges to the idea of a decontextualised independent individual decision-maker that seems implicit in Wiseman's model (1980). Decisions about relocation are significantly influenced by other people and by relationships. They can be both enabled and constrained by socially intertwined biographies, the availability of resources and forms of support that depend on other people, and broader social structures. 
International Journal of Ageing and Later Life

\section{Implications for Policy, Practice and Research}

To support older people's well-being, practitioners with scope to influence relocation processes need to be responsive and sensitive to individual contexts, identities and valued capabilities. For moves to supported settings, people should be encouraged to identify the kind of things that matters to them so judgements about suitability of accommodation can reflect consideration of support for capabilities important for well-being. We suggest that emergent research into the potential of a dedicated "moving on" service to facilitate relocation (Hillcoat-Nalletamby \& Sardani 2019) could usefully adopt a capabilities perspective and be extended to include relocation to supported and care settings.

Our findings add to previous work (Hillcoat-Nalletamby \& Ogg 2014) in challenging the idea that moving is always detrimental to older people's well-being. They support caution against presuming that some kinds of residence are universally better than others, and that the advantages and disadvantages of particular settings are the same for all. Policies supporting "ageing in place" may disproportionately and adversely impact people who are socio-economically disadvantaged, as they can not only constrain mobility but preclude achieving even modest capabilities that are fundamentally important for well-being.

Conceptualising relocation as a socio-spatial process allowed us to illuminate how older adults move to secure well-being and continue to actively negotiate and re-shape their experiences of place and well-being. We suggest that future late-life relocation research should (1) consider both the places where older people relocate from and the places they move into and (2) view moving as a relationally, spatially and temporally negotiated process and not as a set of discrete bounded events.

\section{Corresponding Author}

Manik Gopinath, School of Health, Wellbeing and Social Care, Walton Hall, Milton Keynes, MK7 6AA, United Kingdom. Email: manik.deepak-gopinath@open.ac.uk 
Moving residence in later life

\section{Acknowledgements}

We thank all the study participants for sharing their experiences, and the reviewers and Dr Caroline Holland for their invaluable comments on this article. This work was supported through a Doctoral Fellowship at the School of Social Sciences, University of Dundee.

\section{References}

Andrews, G., Cutchin, M., McCracken, K., Phillips, D. \& Wiles, J. (2007). Geographical gerontology: The constitution of a discipline. Social Science $\mathcal{E}$ Medicine 65(1): 151-168.

Ball, M., Perkins, M., Hollingsworth, C., Whittington, F. \& King, S. (2009). Pathways to assisted living: The influence of race and class. Journal of Applied Gerontology 28(1): 81-108.

Bekhet, A., Zauszniewski, J. \& Nakhla, W. (2009). Reasons for relocation to retirement communities. A qualitative study. Western Journal of Nursing Research 31(4): 461-479.

Bloem, B., van Tilburg, T. \& Thomese, F. (2008). Residential mobility in older Dutch adults: Influence of later life events. International Journal of Ageing and Later Life 3(1): 21-44.

Choi, J. (2004). Evaluation of community planning and life of senior cohousing projects in northern European countries. European Planning Studies 12(8): 1189-1216.

Croucher, K. (2008). Housing Choices and Aspirations of Older People: Research from the New Horizons Programme. London: DCLG.

Cutchin, M. (2001). Deweyan integration: Moving beyond place attachment in elderly migration theory. International Journal of Ageing and Human Development 52(1): 29-44.

Cutchin, M., Owen, S. \& Chang, P. (2003). Becoming "at home" in assisted living residences: Exploring place integration process. Journal of Gerontology B 54(8): 234-243.

Department for Communities and Local Government (DCLG). (2015). English Housing Survey 2015 to 2016: Headline Report. Ministry of Housing, Communities \& Local Government. Available on http://doc.ukdataservice.ac.uk/doc/8186/mrdoc/pdf/8186_2015-16_ehs_headline_report.pdf (Accessed: April 10, 2021). 
International Journal of Ageing and Later Life

Ewen, H. \& Chahal, J. (2013). Influence of late life stressors on the decisions of older women to relocate into congregate senior housing. Journal of Housing for the Elderly 27(4): 392-340.

Finney, N. \& Marshall, A. (2018). Is migration in later life good for wellbeing? A longitudinal study of ageing and selectivity of internal migration. Area 50(4): 492-500.

Finnis, J. (1980). Natural Law and Natural Rights. 1st ed. New York: Oxford University Press.

Fleuret, S. \& Atkinson, S. (2007). Wellbeing, health and geography: A critical review and research agenda. New Zealand Geographer 63(2): 106-118.

Golant, S. M. (2003). Conceptualizing time and behaviour in environmental gerontology: A pair of old issues deserving new thought. The Gerontologist 43(5): 638-648.

Grewal, I., Lewis, J., Flynn, T., Brown, J., Bond, J. \& Coast, J. (2006). Developing attributes for a generic quality of life measure for older people: Preferences or capabilities? Social Science \& Medicine 62(8): 1891-1901.

Harding, A., Parker, J., Hean, S. \& Hemingway, A. (2018). Supply-side review of the UK specialist housing market and why it is failing older people. Housing, Care and Support 21(2): 41-50.

Hillcoat-Nalletamby, S. (2014) The meaning of "independence" for older people in different residential settings. Journal of Gerontology, Series B: Psychological Sciences \& Social Sciences 69(3): 419-430.

Hillcoat-Nalletamby, S. \& Ogg, J. (2014). Moving beyond "ageing in place": Older people's dislikes about their home and neighbourhood environments as a motive for wishing to move. Ageing and Society 34(10): 1771-1796.

Hillcoat-Nalletamby, S. \& Sardani, A. (2019). Decisions about the "if", "when", and "how" of moving home: Can a relocation service help? A Welsh case study. Journal of Housing for the Elderly 33(3): 275-297.

Housing LIN. (2019). The Market for Extra-Care Housing. Housing LIN. Available on https://www.housinglin.org.uk/_assets/Resources/ Housing/Support_materials/Reports/HLIN-Mears_ECH_Market_ Analysis.pdf (Accessed: March 8, 2020).

Jansen, E., Pijper, R. \& de Kam, G. (2017). Expanding capabilities in integrated service areas (ISAs) as communities of care: A study of Dutch older adults' narratives on the life they have reason to value. Journal of Human Development and Capabilities 19(2): 232-248. 
Jennings, T., Perry, T. \& Valeriani, J. (2014). In the best interest of the (adult) child: Ideas about kinship care of older adults. Journal of Family Social Work 17(1): 37-50.

Jungers, C. (2010). Leaving home: An examination of late-life relocation among older adults. Journal of Counselling \& Development 88(4): 416-423.

Laing Buisson. (2017). Care of Older People: UK Market Report. 28th ed. London: LaingBuisson.

Lawton, M. (1977). An ecological theory of ageing applied to elderly housing. Journal of Architectural Education 31(1): 8-10.

Lee, V., Simpson, J. \& Froggatt, K. (2013). A narrative exploration of older people's transitions into residential care. Ageing \& Mental Health 17(1): 48-56.

Leith, K. (2006). "Home is where the heart is ... or is it?" A phenomenological exploration of the meaning of home for older women in congregate housing. Journal of Aging Studies 20(4): 317-333.

Litwak, E. \& Longino, C. (1987). Migration patterns among the elderly: A developmental perspective. The Gerontologist 27(3): 266-272.

Local Government Association (LGA). (2017). Housing Our Ageing Population. Local Government Association. Available on https://www.local. gov.uk/sites/default/ files/documents / 5.17\% 20-\%20Housing $\% 20$ our\%20ageing\%20population_07_0.pdf (Accessed: October 12, 2020).

Luborsky, M., Lysack, C. \& Van Nuil, J. (2011). Refashioning one's place in time: Stories of household downsizing in later life. Journal of Aging Studies 25(3): 243-252.

Massey, D. (1994). Space, Place, and Gender. Minneapolis, MN: University of Minnesota Press.

McCann, M., Grundy, E. \& Reilly, D. (2012). Why is housing tenure associated with a lower risk of admission to a nursing or residential home? Wealth, health and the incentive to keep "my home". Journal of Epidemiology and Community Health 66(2): 166-169.

Merrill, B. \& West, L. (2009). Using Biographical Methods in Social Research. London: Sage.

Nygren, C. \& Iwarsson, S. (2009). Negotiating and effectuating relocation to sheltered housing in old age: A Swedish study over 11 years. European Journal of Ageing 6(3): 177-189.

Office for National Statistics (ONS). (2013). What Does the 2011 Census Tell Us About Older People. Office for National Statistics. Available on 
International Journal of Ageing and Later Life

https:// www.ons.gov.uk/ peoplepopulationandcommunity/birthsdeathsandmarriages/ageing/articles/whatdoesthe2011censustellusaboutolderpeople/2013-09-06\#living-arrangements (Accessed: May $28,2019)$.

Öhlén, J., Balneaves, L., Bottorff, J. \& Brazier, A. (2006). The influence of significant others in complementary and alternative medicine decisions by cancer patients. Social Science \& Medicine 63: 1625-1636.

Peace, S., Holland, C. \& Kellaher, L. (2006). Environment and Identity in Later Life. Growing Older. Maidenhead: Open University Press.

Peace, S., Holland, C. \& Kellaher, L. (2011). "Option recognition" in later life: Variations in ageing in place. Ageing and Society 31(5): 734-757.

Petersen, M. \& Minnery, J. (2013). Understanding daily life of older people in a residential complex: The contribution of Lefebvre's "social space". Housing Studies 28(6): 822-844.

Phillipson, C. (2007). The "elected" and the "excluded": Sociological perspectives on the experience of place and community in old age. Ageing and Society 27(3): 321-342.

Polak, L. \& Green, J. (2016). Using joint interviews to add analytic value. Qualitative Health Research 26(12): 1638-1648.

Pope, N. \& Kang, B. (2010). Residential relocation in later life: A comparison of proactive and reactive moves. Journal of Housing for the Elderly 24(2): 193-207.

Portacolone, E. (2013). The notion of precariousness among older adults living alone in the U.S. Journal of Aging Studies 27(2): 166-174.

Renaut, S., Ogg, J., Petite, S. \& Chamahian, A. (2015). Home environments and adaptations in the context of ageing. Ageing and Society 35(6): 1278-1303.

Ritchie, J. \& Lewis, J. (2003). Qualitative Research Methods. London: Sage.

Robeyns, I. (2016). The capability approach. In E. N. Zalta (ed.), The Stanford Encyclopedia of Philosophy. Available on https://plato.stanford. edu/cgibin/encyclopedia/archinfo.cgi?entry=capability-approach (Accessed: October 3, 2020).

Rowles, G. \& Watkins, J. (2003). History, habit, heart and hearth: On making spaces into places. In K. Schaie, H. Wahl, H. Mollenkopf \& F. Oswald (eds.), Ageing Independently: Living Arrangements and Mobility (pp. 77-98). New York: Springer Publishing Company.

Scottish Government. (2012). Age, Home and Community: A Strategy for Housing for Scotland's Older People: 2012-2021. Scottish Government. 
Available on https://www.gov.scot/binaries/content/documents/ govscot/publications/strategy-plan/2011/12/age-home-community-strategy-housing-scotlands-older-people-2012-2021/ documents/0124256-pdf/0124256-pdf/govscot\%3Adocument/0124256. pdf?forceDownload=true (Accessed: August 8, 2020).

Sen, A. K. (2009). The Idea of Justice. London: Penguin.

Smith, A. E. (2009). Ageing in Urban Neighbourhoods: Place Attachment and Social Exclusion. Ageing and the Lifecourse Series. Bristol: The Policy Press.

Smith, M. L. \& Seward, C. (2009). The relational autonomy of Amartya Sen's capability approach: Incorporating social and individual causes. Journal of Human Development and Capabilities 10(2): 213-235.

Thomése, F. \& Broese van Groenou, M. (2006). Adaptive strategies after health decline in later life: Increasing the person-environment fit by adjusting the social and physical environment. European Journal of Ageing 3(4): 169-177.

Walker, E. \& McNamara, B. (2013). Relocating to retirement living. Australian Occupational Therapy Journal 60: 445-453.

Wiseman, R. (1980). Why older people move, Research on Aging 2: 141-154. 
